\title{
The importance of sound velocity determination for bathymetric survey
}

\author{
Pier Paolo Amoroso ${ }^{1}$, Claudio Parente ${ }^{2}$ \\ ${ }^{1}$ International PhD Programme "Environment, Resources and Sustainable Development", Department of Science and Technology, \\ Parthenope University of Naples, Centro Direzionale, Isola C4, (80143) Naples, Italy \\ 2 Department of Science and Technology, Parthenope University of Naples, Centro Direzionale, Isola C4, (80143) Naples, Italy
}

\begin{abstract}
Bathymetric surveys are carried out whenever there is a need to know the exact morphological trend of the seabed. For a correct operation of the echo sounder, which uses the principle of acoustic waves to scan the bottom and determine the depth, it is important to accurately determine the sound velocity in water, as it varies according to specific parameters (Density, Temperature, and Pressure). In this work, we want to analyse the role of sound velocity determination in bathymetric survey and its impact on the accuracy of depth measurement. The experiments are conducted on data set provided by "Istituto Idrografico della Marina Militare Italiana" (IIM), the official Hydrographic Office for Italy, and acquired in the Ligurian sea. In our case, the formulas of Chen \& Millero (UNESCO), Medwin, and Mackenzie were applied. The introduction of errors on chemical-physical parameters of the water column (Temperature, Pressure, Salinity, Depth) simulating inaccurate measurements, produces considerable impacts on sound velocity determination and subsequently a decrease of the depth value accuracy. The results remark the need to use precise probes and accurate procedures to obtain reliable depth data.
\end{abstract}

\section{Section: RESEARCH PAPER}

Keywords: Bathymetric survey; single beam; multi beam; sound velocity in water; depth measurements

Citation: Pier Paolo Amoroso, Claudio Parente, The importance of sound velocity determination for bathymetric survey, Acta IMEKO, vol. 10, no. 4, article 10, December 2021, identifier: IMEKO-ACTA-10 (2021)-04-10

Section Editor: Silvio Del Pizzo, University of Naples 'Parhenope', Italy

Received May 1, 2021; In final form December 6, 2021; Published December 2021

Copyright: This is an open-access article distributed under the terms of the Creative Commons Attribution 3.0 License, which permits unrestricted use, distribution, and reproduction in any medium, provided the original author and source are credited.

Funding: This work was supported by Parthenope University of Naples, Italy.

Corresponding author: Claudio Parente, e-mail: claudio.parente@uniparthenope.it

\section{INTRODUCTION}

As reported in Huet (2009), "Hydrography is the branch of applied sciences, which deals with the measurement, and description of the physical features of oceans, seas coastal areas, lakes and rivers, as well as with the prediction of their evolution, for the primary purpose of safety of navigation and all other marine activities, including economic development, security and defence, scientific research, and environmental protection" [1].

According to IHO, International Hydrographic Organization [2], hydrographic survey can be defined as the survey of an area of water, but in modern use it includes many other objectives such as measurements of tides, currents, and determination of the physical and chemical properties of water. The main objective is to obtain essential data for the edition of nautical charts with particular interest in the characteristics that may influence navigation [3]. In addition, the hydrographic surveys aim to acquire the information necessary for marine navigation products and for the management, engineering, and science of coastal areas.

The bathymetric surveys belong to the family of hydrographic surveys and are carried out whenever there is a need to precisely know the morphological trend of the seabed [4], [5]. They are therefore preliminary to the realization of maritime and river works and in the case of works already supplied, they are indispensable to verify continuously water heads and dredging volumes [6].

Generally, hydrographic surveys are carried out using a vessel equipped with a precision echo sounder, which uses the principle of acoustic waves to sound the bottom and determine the depth. An accurate determination of the vessel position and attitude as well as a correct functioning of the echo sounder are both fundamental for the quality of the survey results. Using satellites techniques, differential corrections with code measurements allow accuracies estimated to a few meters. Currently, one of the 
most widely used techniques for high-precision positioning of vessels in bathymetric survey is the RTK mode (phase measurements) [7] which allow to achieve centimetre accuracy on the horizontal and vertical plane. Since the effects of the vessel motion on the accuracy of the observed depths and their positioning, attitude (roll, pitch, and heading) and heave must be measured using appropriate instruments, such as inertial sensors that can be also integrated with GPS [8]. A correct functioning of the echo sounder is very important for accurate depth measurement, but an accurate determination of the sound velocity in water is necessary [9]. Once the instrument is activated, the transmitter sends a small amount of electrical energy towards the transducer, which switches it into a sound pulse and sends it towards the seabed. Once it reaches the seabottom, the signal goes back to the transducer. Therefore, the instrument is used to measure the time interval between the transmission and reception of the signal [10], [11]. Two principal types of echo sounder are available, namely the Single beam and the Multibeam. The substantial difference is that the Single beam emits a single sound impulse, while the Multibeam emits a beam of sound impulses, which allow to obtain a greater and more detailed acquisition of the seabed [12].

The Single beam and Multibeam are basic instruments of acoustical oceanography, the discipline that describes the role of the ocean as an acoustic medium by relating oceanic properties to the behaviour of underwater acoustic propagation, noise, etc [13]. The sound velocity in a medium is mostly influenced by the medium itself [14], [15], so it is affected by the conditions of the sea-bottom boundaries as well as by the variation of the chemical-physical parameters of the water volume [16]. In fact, the sound velocity in seawater is defined as a function of the isothermal compressibility, the ratio of specific heats of seawater at constant pressure and constant volume, and the density of seawater [17]. Particularly, the sound velocity in sea water increases with an increase in temperature, salinity or pressure [18]. Temperature decreases from the sea-surface to the seabed, but there are different local variations. The sound velocity profile is very variable near the surface according to the seasons and the hours of the day, due to the heat exchange with the atmosphere, which modifies the temperature and salinity of the sea [16]. If temperature is constant, the velocity sound increases with depth due to the pressure gradient [19].

Normally in literature, the average value of the sound velocity in water is accepted as $1500 \mathrm{~m} / \mathrm{s}$, calculated taking as reference the nominal conditions of the water, characterized by a temperature of $0^{\circ} \mathrm{C}$, a salinity of $35 \mathrm{ppt}$ (parts per thousand) and a pressure of $760 \mathrm{mmHg}$ [20], [21]. This average value, however, can oscillate according to the characteristics of the water, varying between $1387 \mathrm{~m} / \mathrm{s}$ and $1529 \mathrm{~m} / \mathrm{s}$ [17].

Local velocity measurements are quite difficult to perform accurately, whereas its constitutive parameters are more easily quantified. Particular probes, bar check method and empirical formulas, permit to determine the sound velocity. Empirical formulas require physical and chemical parameters, such as depth $(\mathrm{D})$, temperature $(\mathrm{T})$, salinity $(\mathrm{S})$, pressure $(\mathrm{P})$. These parameters can be measured with different types of instruments. There are many different formulas available to calculate the sound velocity in water, and the most popular and accurate are Chen \& Millero (1977) [22]-[25], Del Grosso (1974) [26]-[28], Mackenzie (1981) [29]-[31] and Medwin (1975) [32], [33].

\section{SOUND VELOCITY DETERMINATION}

The determination of the sound velocity in water can be obtained through direct or indirect measurements. Among the systems commonly used to measure the sound velocity in situ, we find the depth velocimeter, which directly measures the sound velocity for a high frequency wave transmitted over an accurately regulated distance. Among the systems commonly used to determine the sound velocity in indirect way, we find specific probes capable of measuring chemical-physical parameters of water as input data. For example, the bathythermograph or the XBT probe [34], [35] measures the water temperature only as a function of depth; to deduce the sound velocity, it is necessary to have the salinity data independently, so it is measured simultaneously by a conductivity meter, integrated in the same device.

The echo sounder is calibrated for water temperature and salinity, or directly to a known depth using the "Bar Check" method (measurement of the immersion depth of a metal bar or disc lowered below the transducer and suspended a graduated cable). This method consists in immersing under the echo sounder transducer, a plate with a square base of edge equal to $60 \mathrm{~cm}$ supported by a chain that has centimetre subdivisions. Dive depths are generally set at $5 \mathrm{~m}, 10 \mathrm{~m}, 15 \mathrm{~m}, 20 \mathrm{~m}$ [36]. Then you go to operate on the settings of the sound velocity in the water proceeding with the measurements until the correct depth value is obtained. This type of operation is repeated for the various control depths at least twice on each depth, and an arithmetic average is calculated on the obtained sound velocity values and set on the instrument. Some systems, however, use all the values read at the various depths. This method is conveniently carried out in shallow water with low currents, gives a mean velocity to the observed depth and simultaneously checks the calibration of the sounder [37].

When indirect measurements are carried out and chemicalphysical parameters of water are available, the application of formulas that permit to calculate sound velocity is necessary. Different formulas are used depending on the depth values, i.e.:

1. Chen \& Millero is only used for depths less than $1000 \mathrm{~m}$;

2. Del Grosso is used only for depths greater than $1000 \mathrm{~m}$;

3. Mackenzie for quick calculations in ocean waters up to $8000 \mathrm{~m}$ depth;

4. Medwin is used for quick calculations in ocean waters up to $1000 \mathrm{~m}$ depth [38].

A range of validity of physical and chemical parameters characterizes every empirical formula. Normally, depths are measured in meters, temperatures are measured in ${ }^{\circ} \mathrm{C}$, salinity is measured in ppt (part for thousand) and pressure is measured in bar. A brief description of each formula is reported below.

The formula Chen \& Millero is denominated as the international algorithm adopted by UNESCO; accurate models than others characterize it, and the equation is the following:

$$
c=C_{w}(T, P)+A(T, P) S+B(T, P) S^{3 / 2}+D(T, P) S^{2},
$$

where

$$
\begin{aligned}
& C_{w}(T, P)=C_{00}+\mathrm{C}_{01} \mathrm{~T}+\mathrm{C}_{02} \mathrm{~T}^{2}+\mathrm{C}_{03} \mathrm{~T}^{3}+\mathrm{C}_{04} \mathrm{~T}^{4}+ \\
& +\mathrm{C}_{05} \mathrm{~T}^{5}+\left(\mathrm{C}_{10}+\mathrm{C}_{11} \mathrm{~T}+\mathrm{C}_{12} \mathrm{~T}^{2}+\mathrm{C}_{13} \mathrm{~T}^{3}+\mathrm{C}_{14} \mathrm{~T}^{4}\right) \mathrm{P}+ \\
& +\left(\mathrm{C}_{20}+\mathrm{C}_{21} \mathrm{~T}+\mathrm{C}_{22} \mathrm{~T}^{2}+\mathrm{C}_{23} \mathrm{~T}^{3}+\mathrm{C}_{24} \mathrm{~T}^{4}\right) \mathrm{P}^{2}+ \\
& +\left(\mathrm{C}_{30}+\mathrm{C}_{31} \mathrm{~T}+\mathrm{C}_{32} \mathrm{~T}^{2}\right) \mathrm{P}^{3}
\end{aligned}
$$




$$
\begin{aligned}
& A(T, P)=\mathrm{A}_{00}+\mathrm{A}_{01} \mathrm{~T}+\mathrm{A}_{02} \mathrm{~T}^{2}+\mathrm{A}_{03} \mathrm{~T}^{3}+\mathrm{A}_{04} \mathrm{~T}^{4}+ \\
& +\left(A_{10}+A_{11} T+A_{12} T^{2}+A_{13} T^{3}++A_{14} T^{4}\right) P+ \\
& +\left(A_{20}+A_{21} T+A_{22} T^{2}+A_{23} T^{3}\right) P^{2}+ \\
& +\left(A_{30}+A_{31} T+A_{32} T^{2}\right) P^{3} \\
& B(T, P)=B_{00}+B_{01} T+\left(B_{10}+B_{11} T\right) P \\
& D(T, P)=D_{00}+D_{10} P .
\end{aligned}
$$

This formula is valid for temperature values included in the range $0{ }^{\circ} \mathrm{C}<T<40{ }^{\circ} \mathrm{C}$, salinity values included in the range $0 \mathrm{ppt}<S<40 \mathrm{ppt}$, and pressure values included in the range 0 bar $<P<1000$ bar [39].

The coefficients in the equations are reported in Table 1.

The Del Grosso equation is used as an alternative to UNESCO algorithm. The formula is the following:

$c(S, T, P)=C_{000}+\Delta C_{\mathrm{T}}+\Delta C_{\mathrm{S}}+\Delta C_{\mathrm{P}}+\Delta C_{\mathrm{STP}}$,

where

$$
\begin{aligned}
& \Delta C_{\mathrm{T}}(T)=C_{\mathrm{T} 1} T+C_{\mathrm{T} 2} T^{2}+C_{\mathrm{T} 3} T^{3}, \\
& \Delta C_{\mathrm{S}}(S)=C_{\mathrm{S} 1} S+C_{\mathrm{S} 2} S^{2}, \\
& \Delta C_{\mathrm{P}}(\mathrm{P})=C_{\mathrm{P} 1} P+C_{\mathrm{P} 2} P^{2}+C_{\mathrm{P} 3} P^{3} \\
& \Delta \mathrm{C}_{\mathrm{STP}}(S, T, P)=C_{\mathrm{TP}} T P+C_{\mathrm{T} 3 \mathrm{P}} T^{3} P+C_{\mathrm{TP} 2} T P^{2}+ \\
& +C_{\mathrm{T} 2 \mathrm{P} 2} T^{2} P^{2}+C_{\mathrm{TP} 3} T P^{3}+C_{\mathrm{ST}} S+C_{\mathrm{ST} 2} S T^{2}+ \\
& +C_{\mathrm{STP}} S T P++C_{\mathrm{S} 2 \mathrm{TP}} S^{2} T P+C_{\mathrm{S} 2 \mathrm{P} 2} S^{2} P^{2} .
\end{aligned}
$$

The coefficient values are shown in Table 2.

This formula is valid for temperature values included in the range $0{ }^{\circ} \mathrm{C}<T<30{ }^{\circ} \mathrm{C}$, salinity values included in the range $30 \mathrm{ppt}<S<40 \mathrm{ppt}$, and pressure values included in the range 0 bar $<P<980.665$ bar.

Unlike Chen \& Millero and Del Grosso, Mackenzie uses depth in the formula for velocity calculation. The formula is:

$$
\begin{aligned}
& c(D, S, T)=1448.96+4.591 T-5.304 \cdot 10^{-2} T^{2}+ \\
& +2.374 \cdot 10^{-4} T^{3}+1.340(S-35)+ \\
& 1.630 \cdot 10^{-2} D+1.675 \cdot 10^{-7} D^{2}- \\
& +1.25 \cdot 10^{-2} T(S-35)-7.139 \cdot 10^{-13} T D^{3} .
\end{aligned}
$$

Table 1. Coefficients of Chen \& Millero formula.

\begin{tabular}{lclclc}
\hline $\mathbf{A}_{00}$ & 1.389 & $\mathbf{B}_{00}$ & -0.01922 & $\mathbf{C}_{22}$ & $2.60 \mathrm{E}-08$ \\
$\mathbf{A}_{01}$ & -0.01262 & $\mathbf{B}_{01}$ & $-4.40 \mathrm{E}-05$ & $\mathbf{C}_{23}$ & $-2.50 \mathrm{E}-10$ \\
$\mathbf{A}_{02}$ & $7.16 \mathrm{E}-05$ & $\mathbf{B}_{10}$ & $7.36 \mathrm{E}-05$ & $\mathbf{C}_{24}$ & $1.04 \mathrm{E}-12$ \\
$\mathbf{A}_{03}$ & $2.01 \mathrm{E}-06$ & $\mathbf{B}_{11}$ & $1.79 \mathrm{E}-07$ & $\mathbf{C}_{30}$ & $-9.80 \mathrm{E}-09$ \\
$\mathbf{A}_{04}$ & $-3.20 \mathrm{E}-08$ & $\mathrm{C}_{00}$ & 1402.388 & $\mathbf{C}_{31}$ & $3.85 \mathrm{E}-10$ \\
$\mathbf{A}_{10}$ & $9.47 \mathrm{E}-05$ & $\mathrm{C}_{01}$ & 5.03711 & $\mathbf{C}_{32}$ & $-2.40 \mathrm{E}-12$ \\
$\mathbf{A}_{11}$ & $-1.30 \mathrm{E}-05$ & $\mathbf{C}_{02}$ & -0.05809 & $\mathbf{D}_{00}$ & 0.001727 \\
$\mathbf{A}_{12}$ & $-6.50 \mathrm{E}-08$ & $\mathbf{C}_{03}$ & 0.000334 & $\mathbf{D}_{10}$ & $-8.00 \mathrm{E}-06$ \\
$\mathbf{A}_{13}$ & $1.05 \mathrm{E}-08$ & $\mathbf{C}_{04}$ & $-1.50 \mathrm{E}-06$ & & \\
$\mathbf{A}_{14}$ & $-2.00 \mathrm{E}-10$ & $\mathbf{C}_{05}$ & $3.15 \mathrm{E}-09$ & & \\
$\mathbf{A}_{20}$ & $-3.90 \mathrm{E}-07$ & $\mathbf{C}_{10}$ & 0.153563 & & \\
$\mathbf{A}_{21}$ & $9.10 \mathrm{E}-09$ & $\mathbf{C}_{11}$ & 0.00069 & & \\
$\mathbf{A}_{22}$ & $-1.60 \mathrm{E}-10$ & $\mathbf{C}_{12}$ & $-8.20 \mathrm{E}-06$ & & \\
$\mathbf{A}_{23}$ & $7.99 \mathrm{E}-12$ & $\mathbf{C}_{13}$ & $1.36 \mathrm{E}-07$ & & \\
$\mathbf{A}_{30}$ & $1.10 \mathrm{E}-10$ & $\mathbf{C}_{14}$ & $-6.10 \mathrm{E}-10$ & & \\
$\mathbf{A}_{31}$ & $6.65 \mathrm{E}-12$ & $\mathbf{C}_{20}$ & $3.13 \mathrm{E}-05$ & & \\
$\mathbf{A}_{32}$ & $-3.40 \mathrm{E}-13$ & $\mathbf{C}_{21}$ & $-1.70 \mathrm{E}-06$ & & \\
\hline
\end{tabular}

This formula is valid for temperature values included in the range $2{ }^{\circ} \mathrm{C}<T<30{ }^{\circ} \mathrm{C}$, salinity values included in the range

(3) $25 \mathrm{ppt}<S<40 \mathrm{ppt}$, and depth values included in the range $0 \mathrm{~m}<D<8000 \mathrm{~m}$ [38].

Medwin is the simplest formula, and it is given as:

$$
\begin{aligned}
& c=1449.2+4.6 T-0.055 T^{2}+0.00029 T^{3}+ \\
& (1.34-0.010 T)(S-35)+0.016 D .
\end{aligned}
$$

This formula, instead, is valid for temperature values included in the range $0{ }^{\circ} \mathrm{C}<\mathrm{T}<35^{\circ} \mathrm{C}$, salinity values included in the range $0 \mathrm{ppt}<S<40 \mathrm{ppt}$ and Depth values included in the range $0 \mathrm{~m}<\mathrm{D}<1000 \mathrm{~m}$.

\section{APPLICATIONS}

\subsection{Hydrographic data}

The "Istituto Idrografico della Marina Militare Italiana (IIM)" provided the data set for this work. The ship used for the survey is the Nave Magnaghi, a hydro-oceanographic ship. The hydrographic activity carried out by the Unit is concretized in the realization of port, coastal and offshore reliefs through sounding operations, research of minimum depths and wrecks,

(8) determination of the topography of the coastline and port works,

\begin{tabular}{|c|c|}
\hline $\mathrm{C}_{000}$ & 1402.392 \\
\hline $\mathrm{C}_{\mathrm{T} 1}$ & $5.01 \mathrm{E}+00$ \\
\hline $\mathrm{C}_{\mathrm{T} 2}$ & $-5.51 E-02$ \\
\hline $\mathrm{C}_{\mathrm{T} 3}$ & $2.22 \mathrm{E}-04$ \\
\hline $\mathrm{C}_{\mathrm{s} 1}$ & $1.33 \mathrm{E}+00$ \\
\hline $\mathrm{C}_{\mathrm{s2}}$ & $1.29 \mathrm{E}-04$ \\
\hline$C_{P 1}$ & 0.1560592 \\
\hline$C_{P 2}$ & $2.45 \mathrm{E}-05$ \\
\hline$C_{P 3}$ & $-8.83 E-09$ \\
\hline$C_{S T}$ & $-1.28 \mathrm{E}-02$ \\
\hline$C_{T P}$ & $6.35 \mathrm{E}-03$ \\
\hline $\mathrm{C}_{\mathrm{T} 2 \mathrm{P2}}$ & $2.66 \mathrm{E}-08$ \\
\hline $\mathrm{C}_{\mathrm{TP2}}$ & $-1.59 \mathrm{E}-06$ \\
\hline $\mathrm{C}_{\mathrm{TP} 3}$ & $5.22 \mathrm{E}-10$ \\
\hline $\mathrm{C}_{\mathrm{T} 3 \mathrm{P}}$ & $-4.38 \mathrm{E}-07$ \\
\hline $\mathrm{C}_{52 \mathrm{P} 2}$ & $-1.62 E-09$ \\
\hline $\mathrm{C}_{\mathrm{ST2}}$ & $9.69 \mathrm{E}-05$ \\
\hline $\mathrm{C}_{\text {S2TP }}$ & $4.86 \mathrm{E}-06$ \\
\hline $\mathrm{C}_{\mathrm{STP}}$ & $-3.41 \mathrm{E}-04$ \\
\hline
\end{tabular}
study of the nature of the seabed etc. The sampling point is

(9) localized near the Ligurian coast named "Riviera di Levante" and has the following coordinates referred to World Geodetic System 84 (WGS-84): $\varphi=43^{\circ} 55^{\prime} 17^{\prime} .53 \mathrm{~N}, \lambda=9^{\circ} 40^{\prime} 55^{\prime \prime} .4 \mathrm{E}$

(10) (Figure 1). This type of data set was obtained by using the "CTD Idronaut-Ocean Seven 316 plus" probe which measures chemicalphysical parameters of water providing in output the values of pressure, temperature, conductivity, salinity, depth and velocity. Particularly, data are provided about every meter of depth, in order to be able to determine the correct vertical profile of the sound velocity. The analysed depths range from $0.99 \mathrm{~m}$ to 324.12 $\mathrm{m}$, the pressure values are provided by the probe in $\mathrm{db}$ (decibar), the temperature in degrees Celsius $\left({ }^{\circ} \mathrm{C}\right)$ and the salinity in parts per thousand (ppt). As reported in the probe technical specification document, pressure and Temperature are directed measured as well as other parameters e. g. conductivity and $\mathrm{pH}$.

Table 2. Coefficients of Del Grosso formula. 
Other parameters such as salinity and Water Density are obtained using specific algorithms available in literature [40]. The probe is characterized by the following accuracy values for direct measurements:

\subsection{E-04 bar for pressure; \\ $2.00 \mathrm{E}-03{ }^{\circ} \mathrm{C}$ for temperature.}

In consideration of the adopted approach of the indirect measurement of the salinity, the accuracy is better than $0.005 \mathrm{ppt}$

\subsection{Results}

In this work, we proceeded with the calculation of the sound velocity in water using three of the formulas previously described (Del Grosso formula is not applicable because the analyzed depths are less than $1000 \mathrm{~m}$ ). Table 3 shows a selection of data supplied by "IDRONAUT CTD" acquired at different depths along the investigated water column, as well as the relative sound velocity values $c_{\mathrm{U}}, c_{\mathrm{ME}}, c_{\mathrm{MA}}$, calculated using respectively the UNESCO formula, the Medwin formula and the Mackenzie formula.
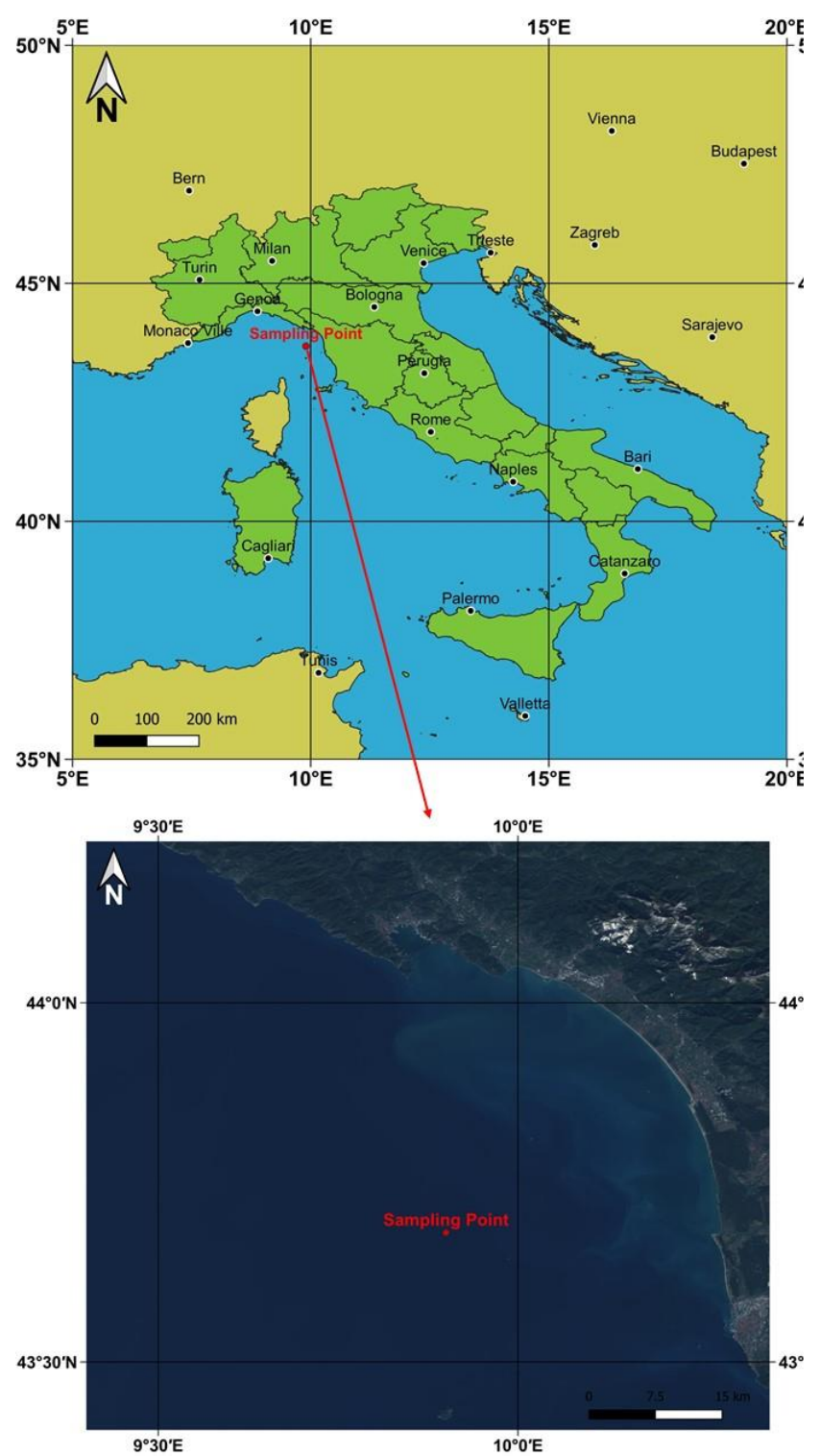

Figure 1. Localization of the sample point: visualization on the Italy map (upper) and on Sentinel-2 Satellite Image of the Ligurian Sea (lower).
Table 3. A selection of values of pressure, temperature and salinity supplied by CTD probe and corresponding velocity of the sound in water calculated by using UNESCO, Medwin and Mackenzie formulas.

\begin{tabular}{ccccccc}
\hline $\boldsymbol{P}($ bar $)$ & $\boldsymbol{D}(\mathbf{m})$ & $\boldsymbol{T}\left({ }^{\circ} \mathbf{C}\right)$ & $\boldsymbol{S}(\mathbf{p p t})$ & $\boldsymbol{C U}_{U}(\mathrm{~m} / \mathbf{s})$ & $\boldsymbol{C}_{\mathrm{ME}}(\mathrm{m} / \mathbf{s})$ & $\boldsymbol{C}_{\mathrm{MA}}(\mathrm{m} / \mathbf{s})$ \\
\hline 0.1 & 0.990 & 23.397 & 38.1408 & 1533.889 & 1533.924 & 1534.569 \\
0.2 & 1.980 & 23.396 & 38.147 & 1533.910 & 1533.945 & 1534.591 \\
0.3 & 2.980 & 23.398 & 38.151 & 1533.934 & 1533.968 & 1534.615 \\
0.4 & 3.970 & 23.397 & 38.154 & 1533.953 & 1533.987 & 1534.635 \\
0.5 & 4.960 & 23.398 & 38.156 & 1533.974 & 1534.006 & 1534.655 \\
0.6 & 5.950 & 23.397 & 38.160 & 1533.994 & 1534.026 & 1534.676 \\
0.7 & 6.940 & 23.389 & 38.163 & 1533.994 & 1534.024 & 1534.676 \\
0.8 & 7.940 & 23.380 & 38.166 & 1533.990 & 1534.020 & 1534.672 \\
0.9 & 8.930 & 23.369 & 38.171 & 1533.987 & 1534.016 & 1534.669 \\
1 & 9.920 & 23.361 & 38.176 & 1533.988 & 1534.017 & 1534.671 \\
5.1 & 50.580 & 16.426 & 38.046 & 1515.445 & 1515.598 & 1515.984 \\
10.1 & 100.170 & 14.034 & 38.180 & 1508.991 & 1509.145 & 1509.458 \\
20.2 & 200.280 & 13.944 & 38.519 & 1510.773 & 1510.865 & 1511.252 \\
32.7 & 324.120 & 14.007 & 38.660 & 1513.210 & 1513.216 & 1513.672 \\
\hline
\end{tabular}

Table 4 shows the statistics (Mean, Standard Deviation, Minimum and Maximum values) of sound velocity values supplied by the adopted formulas.

The sound velocity calculated with the UNESCO formula oscillates between a minimum equal to $1508.988 \mathrm{~m} / \mathrm{s}$ and a maximum equal to $1533.994 \mathrm{~m} / \mathrm{s}$, with an average value equal to $1513.543 \mathrm{~m} / \mathrm{s}$. The velocity calculated with the Medwin formula oscillates between a minimum equal to $1509.142 \mathrm{~m} / \mathrm{s}$ and a maximum equal to $1534.026 \mathrm{~m} / \mathrm{s}$, with an average value of $1513.636 \mathrm{~m} / \mathrm{s}$. Finally, the sound velocity calculated with the Mackenzie formula oscillates between a minimum equal to $1509.455 \mathrm{~m} / \mathrm{s}$ and a maximum equal to $1534.676 \mathrm{~m} / \mathrm{s}$, with an average value equal to $1514.043 \mathrm{~m} / \mathrm{s}$.

In the Table 5, the statistical values of the residuals produced by the comparison between the adopted formulas are reported.

Once the sound velocity was calculated, a systematic error was introduced in each chemical-physical parameter of the water, i.e. temperature, salinity, pressure and depth, in order to evaluate the impact on the determination of the sound velocity. By systematic error we mean, in this case, an incorrect sampling of the parameters in question, simulating probe or human errors during the measurement. The introduced errors are: $0.1,0.5$ and $1{ }^{\circ} \mathrm{C}$

Table 4. Statistics of sound velocity values supplied by the adopted formulas.

\begin{tabular}{cccc} 
& $c_{U}(\mathrm{~m} / \mathrm{s})$ & $c_{\mathrm{ME}}(\mathrm{m} / \mathrm{s})$ & $c_{\mathrm{MA}}(\mathrm{m} / \mathrm{s})$ \\
\hline Mean & 1513.543 & 1513.636 & 1514.043 \\
St. Dev. & 6.686 & 6.666 & 6.747 \\
Min & 1508.988 & 1509.142 & 1509.455 \\
Max & 1533.994 & 1534.026 & 1534.676 \\
\hline
\end{tabular}

Table 5. Statistical values of the residuals produced by the comparison between the adopted formulas.

\begin{tabular}{cccc}
\cline { 2 - 4 } & $\begin{array}{c}C_{\mathrm{ME}}-C_{\mathrm{U}} \\
(\mathrm{m} / \mathrm{s})\end{array}$ & $\begin{array}{c}C_{\mathrm{MA}}-C_{\mathrm{U}} \\
(\mathrm{m} / \mathrm{s})\end{array}$ & $\begin{array}{c}C_{\mathrm{MA}}-C_{\mathrm{ME}} \\
(\mathrm{m} / \mathrm{s})\end{array}$ \\
\hline Mean & 0.094 & 0.501 & 0.407 \\
St. Dev. & 0.050 & 0.063 & 0.087 \\
RMSE & 0.106 & 0.505 & 0.416 \\
Min & 0.006 & 0.462 & 0.312 \\
Max & 0.165 & 0.694 & 0.666 \\
\hline
\end{tabular}


Table 6. Statistical values of the residuals produced by systematic errors for the temperature $\left(0.1-0.5-1{ }^{\circ} \mathrm{C}\right)$ introduced in the adopted formulas.

\begin{tabular}{|c|c|c|c|c|c|}
\hline & \\
\hline & Mean & St. Dev. & RMSE & Min & Max \\
\hline$\Delta c \cup(\mathrm{m} / \mathrm{s})\left(0.1^{\circ} \mathrm{C}\right)$ & 0.311 & 0.020 & 0.312 & 0.249 & 0.321 \\
\hline$\Delta c_{\mathrm{ME}}(\mathrm{m} / \mathrm{s})\left(0.1^{\circ} \mathrm{C}\right)$ & 0.310 & 0.021 & 0.311 & 0.247 & 0.320 \\
\hline$\Delta c_{\mathrm{MA}}(\mathrm{m} / \mathrm{s})\left(0.1^{\circ} \mathrm{C}\right)$ & 0.315 & 0.021 & 0.315 & 0.250 & 0.325 \\
\hline$\Delta c \cup(\mathrm{m} / \mathrm{s})\left(0.5^{\circ} \mathrm{C}\right)$ & 1.549 & 0.102 & 1.553 & 1.239 & 1.597 \\
\hline$\Delta c_{\mathrm{ME}}(\mathrm{m} / \mathrm{s})\left(0.5^{\circ} \mathrm{C}\right)$ & 1.542 & 0.104 & 1.546 & 1.227 & 1.591 \\
\hline$\Delta c_{\mathrm{MA}}(\mathrm{m} / \mathrm{s})\left(0.5^{\circ} \mathrm{C}\right)$ & 1.565 & 0.107 & 1.569 & 1.240 & 1.616 \\
\hline$\Delta c \cup(\mathrm{m} / \mathrm{s})\left(1^{\circ} \mathrm{C}\right)$ & 3.079 & 0.203 & 3.085 & 2.461 & 3.174 \\
\hline$\Delta c_{\mathrm{ME}}(\mathrm{m} / \mathrm{s})\left(1^{\circ} \mathrm{C}\right)$ & 3.063 & 0.207 & 3.070 & 2.437 & 3.161 \\
\hline$\Delta c_{\mathrm{MA}}(\mathrm{m} / \mathrm{s})\left(1^{\circ} \mathrm{C}\right)$ & 3.110 & 0.213 & 3.117 & 2.463 & 3.210 \\
\hline
\end{tabular}

Table 7. Statistical values of the residuals produced by systematic errors for the salinity (0.1-0.5-1 ppt) introduced in the adopted formulas.

\begin{tabular}{cccccc}
\cline { 2 - 5 } & Mean & St. Dev. & RMSE & Min & Max \\
\hline$\Delta c_{\mathrm{U}}(\mathrm{m} / \mathrm{s})(\mathbf{0 . 1} \mathrm{ppt})$ & 0.117 & 0.002 & 0.117 & 0.109 & 0.118 \\
$\Delta c_{\mathrm{ME}}(\mathrm{m} / \mathrm{s})(\mathbf{0 . 1} \mathrm{ppt})$ & 0.119 & 0.003 & 0.119 & 0.111 & 0.120 \\
$\Delta c_{\mathrm{MA}}(\mathrm{m} / \mathrm{s})(\mathbf{0 . 1} \mathrm{ppt})$ & 0.133 & 0.000 & 0.133 & 0.133 & 0.133 \\
$\Delta c_{\mathrm{U}}(\mathrm{m} / \mathrm{s})(\mathbf{0 . 5} \mathrm{ppt})$ & 0.584 & 0.012 & 0.584 & 0.547 & 0.590 \\
$\Delta c_{\mathrm{ME}}(\mathrm{m} / \mathrm{s})(\mathbf{0 . 5} \mathrm{ppt})$ & 0.594 & 0.013 & 0.594 & 0.553 & 0.600 \\
$\Delta c_{\mathrm{MA}}(\mathrm{m} / \mathrm{s})(\mathbf{0 . 5} \mathrm{ppt})$ & 0.664 & 0.000 & 0.664 & 0.664 & 0.664 \\
$\Delta c_{\mathrm{U}}(\mathrm{m} / \mathrm{s})(\mathbf{p p t})$ & 1.169 & 0.025 & 1.169 & 1.094 & 1.181 \\
$\Delta c_{\mathrm{ME}}(\mathrm{m} / \mathrm{s})(\mathbf{p p t})$ & 1.188 & 0.027 & 1.189 & 1.106 & 1.201 \\
$\Delta c_{\mathrm{MA}}(\mathrm{m} / \mathrm{s})(\mathbf{p p t})$ & 1.328 & 0.000 & 1.328 & 1.328 & 1.328 \\
\hline
\end{tabular}

Table 8. Statistical values of the residuals produced by systematic errors for the pressure (0.1-0.5-1 bar) introduced in the adopted formulas.

\begin{tabular}{|c|c|c|c|c|c|}
\hline & Mean & St. Dev. & RMSE & Min & Max \\
\hline$\Delta c$ u $(\mathrm{m} / \mathrm{s})(0.1$ bar $)$ & 0.017 & 0.000 & 0.017 & 0.017 & 0.017 \\
\hline \multicolumn{6}{|l|}{$\Delta c_{\mathrm{ME}}(\mathrm{m} / \mathrm{s})(0.1 \mathrm{bar})$} \\
\hline \multicolumn{6}{|l|}{$\Delta c_{\mathrm{MA}}(\mathrm{m} / \mathrm{s})(0.1 \mathrm{bar})$} \\
\hline$\Delta c_{\cup}(\mathrm{m} / \mathrm{s})(0.5 \mathrm{bar})$ & 0.083 & 0.000 & 0.083 & 0.083 & 0.083 \\
\hline \multicolumn{6}{|l|}{$\Delta c_{\mathrm{ME}}(\mathrm{m} / \mathrm{s})(0.5 \mathrm{bar})$} \\
\hline \multicolumn{6}{|l|}{$\Delta c_{\mathrm{MA}}(\mathrm{m} / \mathrm{s})(0.5 \mathrm{bar})$} \\
\hline$\Delta c_{\mathrm{u}}(\mathrm{m} / \mathrm{s})(1 \mathrm{bar})$ & 0.166 & 0.001 & 0.166 & 0.166 & 0.167 \\
\hline \multicolumn{6}{|l|}{$\Delta c_{\mathrm{ME}}(\mathrm{m} / \mathrm{s})(1 \mathrm{bar})$} \\
\hline$\Delta c_{\mathrm{MA}}(\mathrm{m} / \mathrm{s})(1 \mathrm{bar})$ & & & & & \\
\hline
\end{tabular}

for temperature, $0.1,0.5$ and $1 \mathrm{ppt}$ for salinity, $0.1,0.5$ and $1 \mathrm{bar}$ for pressure, 0.10 .5 and $1 \mathrm{~m}$ for depth. However, those errors are worse than the accuracy values reported for the probe in subchapter 3.1, so to simulate combination of unfavourable environmental situations and poorly accurate operations.

We then proceeded with the calculation of the residuals obtained by comparing the values of sound velocity produced by systematic error with the initial values of sound velocity considered as a reference. Subsequently, the statistical values (Mean, Standard Deviation, RMSE, Minimum and Maximum values) are calculated for each formula, so to define the impact of the systematic errors on the accuracy of sound velocity determination. Table 6 , Table 7, Table 8 and Table 9 show the statistical values of the residual produced by the injection of systematic errors in, respectively, the temperature, salinity, pressure and depth values in each formula.

We finally proceeded with the calculation of the statistical values of the residuals generated by the worst possible
Table 9. Statistical values of the residuals produced by systematic errors for the depth (0.1-0.5-1 $\mathrm{m}$ ) introduced in the adopted formulas.

\begin{tabular}{|c|c|c|c|c|c|}
\hline & Mean & St. Dev. & RMSE & Min & Max \\
\hline \multicolumn{6}{|l|}{$\Delta c \cup(\mathrm{m} / \mathrm{s})(0.1 \mathrm{~m})$} \\
\hline$\Delta c_{\mathrm{ME}}(\mathrm{m} / \mathrm{s})(0.1 \mathrm{~m})$ & 0.002 & 0.000 & 0.002 & 0.002 & 0.002 \\
\hline$\Delta c_{\mathrm{MA}}(\mathrm{m} / \mathrm{s})(0.1 \mathrm{~m})$ & 0.002 & 0.000 & 0.002 & 0.002 & 0.002 \\
\hline \multicolumn{6}{|l|}{$\Delta c \cup(\mathrm{m} / \mathrm{s})(0.5 \mathrm{~m})$} \\
\hline$\Delta c_{\mathrm{ME}}(\mathrm{m} / \mathrm{s})(0.5 \mathrm{~m})$ & 0.008 & 0.000 & 0.008 & 0.008 & 0.008 \\
\hline$\Delta c_{\mathrm{MA}}(\mathrm{m} / \mathrm{s})(0.5 \mathrm{~m})$ & 0.008 & 0.000 & 0.008 & 0.008 & 0.008 \\
\hline \multicolumn{6}{|l|}{$\Delta c \cup(\mathrm{m} / \mathrm{s})(1 \mathrm{~m})$} \\
\hline$\Delta c_{\mathrm{ME}}(\mathrm{m} / \mathrm{s})(1 \mathrm{~m})$ & 0.016 & 0.000 & 0.016 & 0.016 & 0.016 \\
\hline$\Delta c_{\mathrm{MA}}(\mathrm{m} / \mathrm{s})(1 \mathrm{~m})$ & 0.016 & 0.000 & 0.016 & 0.016 & 0.016 \\
\hline
\end{tabular}

Table 10. Statistical values of the residuals produced by combination of systematic errors for temperature and salinity $\left(0.1^{\circ} \mathrm{C}-0.1 \mathrm{ppt}, 0.5^{\circ} \mathrm{C}-0.5 \mathrm{ppt}\right.$ $\left.1{ }^{\circ} \mathrm{C}-1 \mathrm{ppt}\right)$, introduced in the adopted formulas.

\begin{tabular}{|c|c|c|c|c|c|}
\hline & Mean & St. Dev. & RMSE & Min & Max \\
\hline$\Delta c_{\cup}(\mathrm{m} / \mathrm{s})\left(0.1^{\circ} \mathrm{C}-0.1 \mathrm{ppt}\right)$ & 0.428 & 0.023 & 0.429 & 0.358 & 0.439 \\
\hline$\Delta c_{\mathrm{ME}}(\mathrm{m} / \mathrm{s})\left(0.1^{\circ} \mathrm{C}-0.1 \mathrm{ppt}\right)$ & 0.429 & 0.024 & 0.429 & 0.357 & 0.440 \\
\hline$\Delta c_{\mathrm{MA}}(\mathrm{m} / \mathrm{s})\left(0.1^{\circ} \mathrm{C}-0.1 \mathrm{ppt}\right)$ & 0.447 & 0.021 & 0.448 & 0.382 & 0.458 \\
\hline$\Delta c \cup(\mathrm{m} / \mathrm{s})\left(0.5^{\circ} \mathrm{C}-0.5 \mathrm{ppt}\right)$ & 2.131 & 0.114 & 2.134 & 1.784 & 2.185 \\
\hline$\Delta c_{\mathrm{ME}}(\mathrm{m} / \mathrm{s})\left(0.5^{\circ} \mathrm{C}-0.5 \mathrm{ppt}\right)$ & 2.134 & 0.117 & 2.137 & 1.777 & 2.189 \\
\hline$\Delta c_{\mathrm{MA}}(\mathrm{m} / \mathrm{s})\left(0.5^{\circ} \mathrm{C}-0.5 \mathrm{ppt}\right)$ & 2.229 & 0.107 & 2.232 & 1.904 & 2.280 \\
\hline$\Delta c \cup(\mathrm{m} / \mathrm{s})\left(1^{\circ} \mathrm{C}-1 \mathrm{ppt}\right)$ & 4.237 & 0.227 & 4.244 & 3.547 & 4.344 \\
\hline$\Delta c_{\mathrm{ME}}(\mathrm{m} / \mathrm{s})\left(1^{\circ} \mathrm{C}-1 \mathrm{ppt}\right)$ & 4.242 & 0.233 & 4.248 & 3.533 & 4.352 \\
\hline$\Delta c_{\mathrm{MA}}(\mathrm{m} / \mathrm{s})\left(1^{\circ} \mathrm{C}-1 \mathrm{ppt}\right)$ & 4.437 & 0.213 & 4.442 & 3.790 & 4.538 \\
\hline
\end{tabular}

combination of the systematic errors on temperature and salinity. The results of this calculation are shown in the table 10

In the end, the estimate of the errors on the depths was calculated. To provide the reader with an idea of this error dimension, average values of sound velocity in water were taken, calculated using the three formulas, every $100 \mathrm{~m}, 200 \mathrm{~m}$ and a single average value over the entire column of water, both with and without systematic errors.

Figure 2 shows the variability of the sound velocity in the case of UNESCO formula application, when we introduced systematic errors on temperature $\left(0.5^{\circ} \mathrm{C}\right)$, salinity $(0.5 \mathrm{ppt})$ and both $\left(0.5^{\circ} \mathrm{C}-0.5 \mathrm{ppt}\right)$.

Table 11 shows the RMSE values of the differences between the known and the calculated depths by using different sound

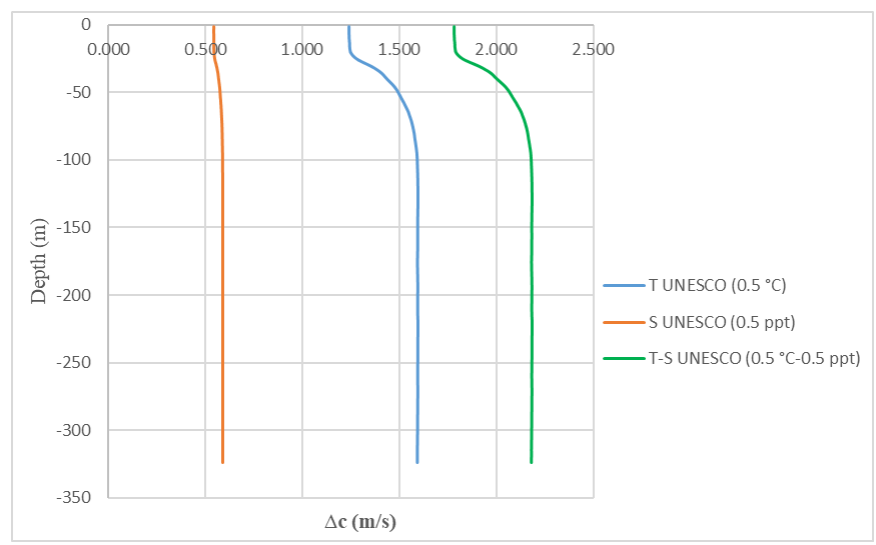

Figure 2. Impact on the sound velocity in water caused by systematic errors on $\mathrm{T}, \mathrm{S}$ and $\mathrm{T}-\mathrm{S}$. 
Table 11. RMSE values of the differences between the known and the calculated depths using velocity sound values derived from different approaches.

\begin{tabular}{|c|c|c|c|}
\hline Velocity values taken on: & $\begin{array}{c}R M S E_{\mathrm{U}} \\
(\mathrm{m})\end{array}$ & $\begin{array}{c}R M S E_{\mathrm{ME}} \\
(\mathrm{m})\end{array}$ & $\begin{array}{c}R M S E_{\mathrm{MA}} \\
(\mathrm{m})\end{array}$ \\
\hline Entire water column & 0.260 & 0.250 & 0.263 \\
\hline Every 100 m & 0.111 & 0.107 & 0.121 \\
\hline Entire water column $\left(0.1^{\circ} \mathrm{C}\right)$ & 0.246 & 0.236 & 0.243 \\
\hline Entire water column $\left(0.5^{\circ} \mathrm{C}\right)$ & 0.245 & 0.243 & 0.248 \\
\hline Entire water column $\left(1^{\circ} \mathrm{C}\right)$ & 0.353 & 0.356 & 0.360 \\
\hline Every $100 \mathrm{~m}\left(0.1^{\circ} \mathrm{C}\right)$ & 0.116 & 0.116 & 0.128 \\
\hline Every $100 \mathrm{~m}\left(0.5^{\circ} \mathrm{C}\right)$ & 0.216 & 0.224 & 0.229 \\
\hline Every $100 \mathrm{~m}\left(1^{\circ} \mathrm{C}\right)$ & 0.388 & 0.397 & 0.401 \\
\hline Entire water column (0.1 ppt) & 0.254 & 0.244 & 0.251 \\
\hline Entire water column (0.5 ppt) & 0.237 & 0.229 & 0.234 \\
\hline Entire water column (1 ppt) & 0.235 & 0.231 & 0.239 \\
\hline Every 100 m (0.1 ppt) & 0.111 & 0.109 & 0.123 \\
\hline Every 100 m (0.5 ppt) & 0.130 & 0.134 & 0.148 \\
\hline Every 100 m (1 ppt) & 0.178 & 0.188 & 0.207 \\
\hline Entire water column $\left(0.1^{\circ} \mathrm{C}-0.1 \mathrm{ppt}\right)$ & 0.241 & 0.233 & 0.239 \\
\hline Entire water column $\left(0.5^{\circ} \mathrm{C}-0.5 \mathrm{ppt}\right)$ & 0.276 & 0.277 & 0.286 \\
\hline Entire water column $\left(1^{\circ} \mathrm{C}-1 \mathrm{ppt}\right)$ & 0.470 & 0.477 & 0.497 \\
\hline Every $100 \mathrm{~m}\left(0.1^{\circ} \mathrm{C}-0.1 \mathrm{ppt}\right)$ & 0.121 & 0.123 & 0.134 \\
\hline Every $100 \mathrm{~m}\left(0.5^{\circ} \mathrm{C}-0.5 \mathrm{ppt}\right)$ & 0.279 & 0.290 & 0.302 \\
\hline Every $100 \mathrm{~m}\left(1^{\circ} \mathrm{C}-1 \mathrm{ppt}\right)$ & 0.526 & 0.538 & 0.560 \\
\hline
\end{tabular}

velocity values, those obtained from different approaches, i.e. using UNESCO formula (RMSE $E_{\mathrm{U}}$, Medwin formula (RMSE $\left.E_{\mathrm{ME}}\right)$ and Mackenzie formula (RMSE $E_{\mathrm{MA}}$ ), averaging the sound velocity values on sections $(100 \mathrm{~m})$ or on the entire water column, injecting errors in temperature $\left(0.1-0.5-1{ }^{\circ} \mathrm{C}\right)$, salinity $(0.1-0.5-1$ ppt) or both.

\subsection{Discussions}

The results highlight how the values of sound velocity in water obtained by means of the three formulas are like each other. In particular, as reported in Table 5 , it is possible to see how the UNESCO formula and the Medwin formula are very similar to each other, as they show a very small RMSE, while the Mackenzie formula, compared to the other two, approximates the sound velocity values differently in the same conditions.

From the results shown in the previous tables, temperature and salinity are the parameters that have the greatest effect on the determination of the sound velocity in water. In fact, the introduction of systematic errors on them produces impacts greater than depth and pressure. As regards the temperature, the parameter that has the greatest influence compared to the others, there is an increase in the RMSE value, in particular with the presence of an error of $1{ }^{\circ} \mathrm{C}$, an RMSE equal to $3.088 \mathrm{~m} / \mathrm{s}$ is obtained, as shown in Table 6 . These results are approximately similar for all formulas. For salinity, another parameter with strong influence, as shown in Table 7, we can see that the results obtained by using the UNESCO formula and the Medwin formula are very similar, while regarding the Mackenzie formula, we can see how an important variation of the velocity values is obtained, but this remains constant along the water column. This result is highlighted by the standard deviation values.

For the pressure and the depth, the situation is the opposite, as they are the parameters that have minor effects on the determination of the velocity, in fact the impact produced by the introduction of systematic errors can be considered almost negligible. For pressure, we have an RMSE much smaller compared to the one seen previously. It can be noted that even with the presence of a systematic error equal to $1 \mathrm{bar}$, the RMSE is almost negligible, showing a value of $0.16 \mathrm{~m} / \mathrm{s}$ as shown in Table 8. Finally, for the depth, as shown in Table 9, we get the smallest values of RMSE. Also for these two parameters, the formulas show similar values.

In the case of the worst combination generated by the simultaneous introduction of systematic errors on temperature and salinity, Table 10 shows very important results. The incorrect determination of these parameters, combined with each other, leads to an RMSE ranging from $0.428 \mathrm{~m} / \mathrm{s}$ (for a systematic error of $0.1{ }^{\circ} \mathrm{C}-0.1 \mathrm{ppt}$ ) up to $4.248 \mathrm{~m} / \mathrm{s}$ (for a systematic error of $\left.1{ }^{\circ} \mathrm{C}-1 \mathrm{ppt}\right)$. Also in this case, the values obtained by the formulas of UNESCO and Medwin are similar, while the Mackenzie formula shows a slight increase in the obtained values.

In the end, Table 11 shows the RMSE values for the depth associated with the resulting velocity values. In particular, it can be noted that, as more velocity values are taken along the water column, the RMSE value tends to decrease. In fact, for a single velocity value over the entire water column, an RMSE equal to $0.260 \mathrm{~m}$ is obtained, while for velocity values taken every $100 \mathrm{~m}$, an RMSE equal to $0.110 \mathrm{~m}$ is obtained. We can also note that a systematic error on velocity naturally leads to an error on depth, even taking multiple velocity values along the water column, generating an RMSE equal to $0.560 \mathrm{~m}$ in the worst possible case, i.e. with the presence of a systematic error on both temperature and salinity.

\section{CONCLUSIONS}

Bathymetric surveys are typically carried out using techniques that exploit the propagation of acoustic waves in water. Therefore, the correct determination of the sound velocity in water is of fundamental importance. It was found that an error on the chemical-physical parameters of the water (temperature, pressure, salinity, depth) due to an inaccurate instrument calibration, or, rather, to the use of a wrong model for one of them, can impact significantly on sound velocity determination. In particular, this article provides a measurement of the errors that can be produced.

For our application, the formulas of UNESCO, Medwin and Mackenzie have been taken into consideration and systematic errors on the four parameters have been simulated. The inaccuracy of temperature and salinity measurements produces the greatest effects. Particularly, the results remark that the sound velocity is very sensitive to the variation of the temperature.

An error on the determination of the sound velocity in water leads to a non-negligible error on the depth. It has been seen that using a single sound velocity value over the entire water column, affected by a combination of systematic errors for temperature and salinity, generates errors that can reach about $0.5 \mathrm{~m}$. Of course, taking more different velocity values as reference along the water column allows you to determine the depth of the bottom more accurately, but even in this case, you risk having non negligible errors.

It is possible to conclude that the sound velocity in water represents a very important parameter in bathymetric surveys, and therefore it must necessarily be determined with the highest possible accuracy. Our experiments do not permit to evaluate the best method for indirect measurement of sound in water: the 
paper highlights the impact of inaccurate determination of temperature, pressure and salinity on the bathymetric survey results. Extremely precise probes for direct measurement now available are to prefer to improve the depth determination.

\section{ACKNOWLEDGEMENT}

This work synthesizes results of experiments executed within a research project performed in the Laboratory of Geomatics, Remote Sensing and GIS of the "Parthenope" University of Naples. We would like to thank the technical staff for their support.

\section{REFERENCES}

[1] M. Huet, Marine Spatial Data Infrastructure, An IHO Perspective: Data, products, standards and policies, International Hydrographic Bureau, Monaco (2009).

[2] M. J. Umbach, Hydrographic manual, Department of Commerce, National Oceanic and Atmospheric Administration, National Ocean Survey, 20 (2), (1976).

[3] R. M. Alkan, N.O. Aykut, Evaluation of Recent Hydrographic Survey Standards, In Proc. of the 19th International Symposium on Modern Technologies, Education and Professional Practice in Geodesy and Related Fields, pp. 116-130, (2009).

[4] J. V. Gardner, P. Dartnell, L. A. Mayer, J. E. H. Clarke, Geomorphology, acoustic backscatter, and processes in Santa Monica Bay from multibeam mapping, Marine Environmental Research, 56 (1-2), pp.15-46, (2003). DOI: $10.1016 /$ S0141-1136(02)00323-9

[5] T. A. Kearns, J. Breman, Bathymetry-The art and science of seafloor modeling for modern applications, Ocean globe, pp. 136, (2010).

[6] L. M. Pion, J. C. M. Bernardino, Dredging Volumes Prediction for the Access Channel of Santos Port Considering Different Design Depths, TransNav International Journal on Marine Navigation and Safety of Sea Transportation 12, (2018).

DOI: $10.12716 / 1001.12 .03 .09$

[7] D. Popielarczyk, RTK water level determination in precise inland bathymetric measurements, In Proceedings of the 25th International Technical Meeting of The Satellite Division of the Institute of Navigation (ION GNSS 2012), September (2012), pp. 1158-1163.

[8] Manual on Hydrography, Publication C-13, 1 St Edition, Published by the International Hydrographic Bureau, May(2005).

[9] G. B. Mills, International hydrographic survey standards, The International Hydrographic Review, (1998).

[10] G. Antonelli, F. Arrichiello, A. Caiti, G. Casalino, D. De Palma, G. Indiveri, M. Razzanelli, L. Pollini, E. Simetti, ISME activity on the use of autonomous surface and underwater vehicles for acoustic surveys at sea, ACTA IMEKO, 7(2), pp. 24-31, (2018). DOI: $10.21014 /$ acta imeko.v7i2.539

[11] C. Parente, and A. Vallario, Interpolation of Single Beam Echo Sounder Data for 3D Bathymetric Model, Int. J. Adv. Comput. Sci. Appl, 10, pp.6-13, (2019). DOI: $10.14569 / \mathrm{IJACSA} .2019 .0101002$

[12] I. Parnum, J. Siwabessy, A. Gavrilov, M. Parsons, A comparison of single beam and multibeam sonar systems in seafloor habitat mapping, In Proc. 3rd Int. Conf. and Exhibition of Underwater Acoustic Measurements: Technologies \& Results, Nafplion, Greece, June (2009), pp. 155-162.

[13] H. Medwin, Sounds in the sea: From ocean acoustics to acoustical oceanography, Cambridge University Press, (2005).

[14] J. W. S. Rayleigh, Theory of Sound, 2(255-266), Macmillan, London, (1894).

[15] D. Agrez, S. Begus, Evaluation of pressure effects on acoustic thermometer with a single waveguide, Acta Imeko, 7(4), pp. 42 47, (2019).

DOI: $10.21014 /$ acta imeko.v7i4.576
[16] X. Lurton, An introduction to underwater acoustics: principles and applications, Springer Science \& Business Media, (2002).

[17] P. C. Etter, Underwater acoustic modeling and simulation, CRC press, (2018). DOI: $10.1201 / 9781315166346$

[18] L. D. Talley, Descriptive physical oceanography: an introduction, Academic Press, (2011) DOI: $10.1016 /$ B978-0-7506-4552-2.10001-0

[19] Introduction to sonar, Bureau of Naval Personnel Navy training course, 2nd ed., Washington, D.C.: U.S. Bureau of Naval Personnel, (1963).

[20] A. E. Ingham, Hydrography for the Surveyor and Engineer, 3rd Edn., Blackwell Scientific Publications, London, pp. 132, (1992).

[21] S. Jamshidi, M. N. Abu Bakar, An Analysis on sound speed in seawater using CTD data, Journal of applied sciences, 10(2), pp. 132-138, (2010). DOI: $10.3923 /$ jas. 2010.132 .138

[22] C. T. Chen, R. A. Fine, F. J. Millero, The equation of state of pure water determined from sound speeds, The Journal of Chemical Physics, 66(5), pp. 2142-2144, (1977). DOI: $10.1063 / 1.434179$

[23] C. T. Chen, F. J. Millero, The equation of state of seawater determined from sound speeds, Journal of Marine Research, 36(4), pp. 657-691, (1978).

[24] F. J. Millero, C. T. Chen, A. Bradshaw, K. Schleicher, A new highpressure equation of state for seawater, Deep Sea Research Part A. Oceanographic Research Papers, 27(3-4), pp. 255-264, (1980). DOI: $10.1016 / 0198-0149(80) 90016-3$

[25] F. J. Millero, History of the equation of state of seawater, Oceanography, 23(3), pp.18-33, (2010). DOI: $10.5670 /$ oceanog.2010.21

[26] V. A. Del Grosso, C. W. Mader. Speed of sound in pure water, The Journal of the Acoustical Society of America, 52(5B), pp. 1442-1446, (1972).

DOI: $\underline{10.1121 / 1.1913258}$

[27] F. Filiciotto, G. Buscaino, The role of sound in the aquatic environment, Ecoacoustics, pp.61-79, (2017). DOI: $10.1002 / 9781119230724 . c h 4$

[28] L. Li, T. Wang, L. Yang, C. Gu, H. Liang, Modeling of sound speed in UWASN, In 2018 IEEE 15th International Conference on Networking, Sensing and Control (ICNSC), IEEE., March (2018), pp. 1-6. DOI: $10.1109 /$ ICNSC. 2018.8361308

[29] C. C. Leroy, Development of simple equations for accurate and more realistic calculation of the speed of sound in seawater, The Journal of the Acoustical Society of America, 46(1B), pp. 216-226, (1969).

DOI: $10.1121 / 1.1911673$

[30] K. V. Mackenzie, Discussion of seawater sound-speed determinations, The Journal of the Acoustical Society of America, 70(3), pp. 801-806, (1981). DOI: $\underline{10.1121 / 1.386919}$

[31] K. V. Mackenzie, Nine-term equation for sound speed in the oceans, The Journal of the Acoustical Society of America, 70(3), pp.807-812, (1981). DOI: $10.1121 / 1.386920$

[32] H. Medwin, Speed of sound in water: A simple equation for realistic parameters, The Journal of the Acoustical Society of America, 58(6), pp.1318-1319, (1975). DOI: $\underline{10.1121 / 1.380790}$

[33] C. C. Leroy, S. P. Robinson, M. J. Goldsmith, A new equation for the accurate calculation of sound speed in all oceans, The Journal of the Acoustical Society of America, 124(5), pp.2774-2782, (2008). DOI: $10.1121 / 1.2988296$

[34] R. H. Heinmiller, C. C. Ebbesmeyer, B. A. Taft, D. B. Olson, O. P. Nikitin, Systematic errors in expendable bathythermograph (XBT) profiles, Deep Sea Research Part A. Oceanographic Research Papers, 30(11), pp. 1185-1196, (1983). DOI: 10.1016/0198-0149(83)90096-1 
[35] L. Cheng, J. Abraham, G. Goni, T. Boyer, S. Wijffels, R. Cowley, V. Gouretski, F. Reseghetti, S. Kizu, S. Dong, F. Bringas, M. Goes, L. Houpert, J. Sprintall, J. Zhu, XBT science: Assessment of instrumental biases and errors, Bulletin of the American Meteorological Society, 97(6), pp. 924-933., (2016). DOI: 10.1175/BAMS-D-15-00031.1

[36] M. J. Langland, Bathymetry and sediment-storage capacity change in three reservoirs on the Lower Susquehanna River, 1996-2008, Reston, VA: US Geological Survey, (2009). DOI: $10.3133 / \operatorname{sir} 20095110$

[37] C. D. Maunsell, The Speed of Sound in Water, Canadian Acoustics, 4(3), pp. 2-4, (1976).
[38] K. H. Talib, M. Y. Othman, S. A. H. Sulaiman, M. A. M. Wazir, A. Azizan, Determination of speed of sound using empirical equations and SVP, IEEE 7th International Colloquium on Signal Processing and its Applications, IEEE, March (2011), pp. 252256. DOI: $10.1109 /$ CSPA.2011.5759882

[39] R. M. Alkan, Y. Kalkan, N. O. Aykut, Sound velocity determination with empirical formulas and bar check, In Proceedings of 23rd FIG Congress, Munich, October (2006).

[40] N. P. Fofonoff, R.C. Millard Jr., Algorithms for computation of fundamental properties of seawater, UNESCO technical papers in marine science, 44, (1983). 